ISSN 2078-6441. Вісник Львівського університету. Серія географічна. 2018. Випуск 52. С. 42-52.

Visnyk of the Lviv University. Series Geography. 2018. Issue 52. P. 42-52.

http:/ / dx.doi.org/10.30970/vgg.2018.52.10167

631.44:632.125(438.42)

\title{
олодимир ськевич
}

ьвівський н ціон льний університет імені в н

вул. . орошенк, 41, 79007, м. ьвів, кр їн, e-mail: haskevich_vg@ukr.net

ерново-підзолисті (Albeluvisoils Gleyic), лучні (Gleyic Chernic Phaeozems) т дернові (Arenosols) грунти є типовими для території лого олісся. природному ст ні ці грунти перезволожені, м ють нез довільні фізичні вл стивості, м лоприд тні для сільськогоспод рського використ ння. ісля осушув льних меліор цій грунти інтенсивно використовують під ріллею, п совищ ми, сінож ттями.

сушення призвело до суттєвого зниження рівня грунтових вод, спричинило посилення промивного водного режиму, інтенсифікув ло процеси лесив жу, що позн чилось н фізичних вл стивостях грунтів, зокрем, н гр нулометричному скл ді. меліоров них територіях посилил сь ридиз ція, ктивізув лись дефляційні процеси. дефльов них дерново-підзолистих грунт х виявлено полегшення гр нулометричного скл ду вн слідок зменшення в орних горизонт х вмісту мулу і дрібного пилу.

ільш суттєвих змін з зн є гр нулометричний скл д грунтів вн слідок посилення промивного водного режиму після осушення. міст фізичної глини в орному горизонті дерновопідзолистих зв'язнопіщ них грунтів зменшився н 1,63\%, супіщ них - н 5,30-6,20\%. гумусово- кумулятивному орному горизонті лучних грунтів вміст фізичної глини зменшився н 2,40-1,60\%, дернових грунтів - н 1,27-6,39\%. имив ння дрен жними вод ми дрібних гр нулометричних фр кцій призводить до збільшення вмісту піщ них фр кцій і полегшення гр нулометричного скл ду грунтів, зміни гр д ції грунтів н рівні різновиду.

меншення вмісту фізичної глини зумовлює погіршення фізичних, фізико-хімічних, грономічних вл стивостей грунтів, отже, спричиняє розвиток дегр д ційних процесів: знеструктурення, дефляції, дегуміфік ції, дегр д ції водно-повітряного і поживного режимів, ридиз ції. е д ло підст ву тр ктув ти полегшення гр нулометричного скл ду осушених грунтів як "гр нулометричну дегр д цію” і з числити іiї до типу фізичної дегр д ції грунтів.

лючові слов : ле олісся, осушув льні меліор ції, грунти, гр нулометричний скл д, фізичн глин, гр нулометричн дегр д ція.

сушув льні меліор ції н лому оліссі 3 поч тков ні ще н прикінці -н поч тку ст., одн к н йбільших темпів досягли в 60-70-х рок х ст., коли проведено т к зв ні широком сшт бні осушув льні меліор ції. одного боку, вони сприяли з лученню в інтенсивне сільськогоспод рське виробництво зн чних площ p ніше м лопродуктивних перезволожених і з болочених земель, з іншого, - спричинили суттєві зміни природного середовищ, зокрем, грунтів і грунтового покриву регіону. сушення перезволожених грунтів лого олісся н йсуттєвіше вплинуло н

(C) ськевич ., 2018 
грунтові режими і процеси т призвело до змін морфологічних особливостей, фізичних, фізико-хімічних т водно-фізичних вл стивостей грунтів.

ерез специфіку природних умов, процесів грунтотворення і генези грунти лого олісся м ють низьку зд тність протистояти нтропогенному пресингу. рив ле сільськогоспод рське використ ння грунтів, яке супроводжув лось з стосув нням в жкої техніки і зн рядь обробітку, тот льними осушув льними меліор ціями, б йдужим, ч сто спожив цьким ст вленням до грунтів і земельних ресурсів, спричинило розвиток дегр д ційних процесів. к н слідок, ст н грунтів і земель окремих регіонів

лого олісся близький до критичного. роблем дегр д ції грунтів у р зі їхнього трив лого т інтенсивного сільськогоспод рського використ ння н лежить до н й ктульніших проблем суч сного грунтозн вств , екології, землеробств .

ст нніми десятиліттями фізичним вл стивостям грунтів і гр нулометричному скл ду, зокрем , його впливу н вл стивості грунтів і особливості сільськогоспод рського використ ння приділяють зн чну ув гу. уч сні уявлення про гр нулометричний скл д грунтів висвітлені в пр цях . едведєв , . ктіонової, . еїн , рп чевського т ін. [5-8, 10, 11]. втори сх р ктеризув ли теоретико-методологічні підходи до вивчення гр нулометричного скл ду грунтів, його зн чення для формув ння грунтових режимів, впливу н екологічний ст н грунтів, проблеми оптиміз ції фізичного ст ну грунтів різного гр нулометричного скл ду з умови інтенсивного сільськогоспод рського пресингу.

одноч с вивченість зміни гр нулометричного скл ду грунтів 3 умов трив лого нтропогенного н в нт ження, осушних меліор цій і зумовлених цим дегр д ційних процесів є недост тньою. еякі пит ння зміни гр нулометричного скл ду грунтів під впливом осушення розглянуто в пр цях . люк т ін., т кож . ерезін , . обровольського, . йдельм н , . ськевич , . ичини $[1-4,9]$.

ому дослідження гр нулометричного скл ду грунтів лого олісся т його зміни під впливом осушення, впливу н розвиток дегр д ційних процесів $є$ кту льними. х н терен х лого олісся проведено вперше.

ід ч с досліджень ми пр гнули вивчити фізичні вл стивості грунтів лого олісся, їхню тр нсформ цію під впливом осушув льних меліор цій т сільськогоспод рського використ ння. е визн чило мету, об'єкт, предмет і кту льність досліджень, н укове і прикл дне зн чення отрим них результ тів.

em досліджень - сх р ктеризув ти гр нулометричний скл д грунтів лого

олісся в контексті розвитку дегр д ційних процесів. б'єкт досліджень - дерновопідзолисті, лучні т дернові неосушені й осушені грунти лого олісся. редмет досліджень - вміст гр нулометричних фр кцій у грунт х т їхня змін під впливом осушення, розвиток дегр д ційних процесів.

р нулометричний скл д грунтів досліджув ли н ст ціон рних т н півст ціон pних ділянк $\mathrm{x}, 3$ кл дених у меж $\mathrm{x}$ тинського т ідподільського природних $\mathrm{p}$ йонів

лого олісся. ослідження гр нулометричного скл ду осушених грунтів проводили в розріз х, з кл дених м ксим льно н ближено до місць з кл д ння грунтових розрізів до проведення осушення. рив лість осушення грунтів з критим дрен жем ст новить 25-28 років. ході дослідження грунтів використ но порівняльно-геогр фічний, порівняльно-профільний т н літичний методи. 
н літичні роботи викон но в сертифіков ній л бор торії н лізу грунтів к федри грунтозн вств і геогр фії грунтів ьвівського н ціон льного університету імені в н р нк відповідно до методик і ст нд ртів, прийнятих в кр їні.

ерново-підзолисті (Albeluvisoils Gleyic), лучні (Gleyic Chernic Phaeozems) т дернові (Arenosols) грунти є типовими для території лого олісся. они ст новлять основу грунтових ресурсів, після проведення осушув льних меліор цій їх інтенсивно використовують під ріллею, прис дибними землями, п совищ ми, сінож ттями тощо. сушення призвело до суттєвого зниження рівня грунтових вод, спричинило посилення промивного водного режиму, інтенсифікув ло процеси лесив жу, що позн чилось н фізичних вл стивостях грунтів, зокрем, н гр нулометричному скл ді. и прон лізув ли вміст фр кцій мулу (ч стинки розміром менше 0,001 мм), дрібного пилу (ч стинки розміром 0,005-0,001 мм), які н йбільше підд ються видув нню вітром т вимив нню дрен жними вод ми до і після осушення грунтів. л сне кількість мулу і дрібного пилу позн ч ється н вмісті фізичної глини (ч стинки розміром менше 0,01 мм).

р нулометричний скл д, як консерв тивн вл стивість грунту, усп дков ний від грунтотворної породи, досить стійкий як до зовнішніх, нтропогенних, т к і до внутрішніх грунтових процесів. ля того щоб суттєво змінити вміст і співвідношення гр нулометричних фр кцій у меж х генетичного горизонту чи у грунтовому профілі 3 г лом, необхідний трив лий ч с окультурення бо еволюції грунту. кими природно- нтропогенними і вл сне нтропогенними процес ми тр нсформ ції гр нулометричного скл ду, згідно з дослідженнями, є дефляція т осушув льні меліор ції.

ефляційні процеси призводять до змін гр нулометричного скл ду дерновопідзолистих грунтів, які н йбільше виявляються в орному горизонті. ефльов ні грунти м ють піщ ний і зв'язнопіщ ний, менше - супіщ ний гр нулометричний скл д.

результ т ми досліджень, сум фр кцій фізичної глини в орному горизонті сл бкодефльов них дерново-сл бкопідзолистих грунтів ст новить $6,16 \%$, середньодефльов них - 4,08-4,92 \%, сильнодефльов них - 2,16-7,44 \%; у дерново-середньопідзолистих сл бодефльов них $-6,84-14,20 \%[1,2]$. підст ві порівняння д них гр нулометричного скл ду гумусово-елюві льного горизонту недефльов них і орного ш ру різного ступеня дефльов них грунтів з'ясов но, що в дефльов них грунт х простежується тенденція до зменшення вмісту фізичної глини, особливо в середньо- і сильнодефльов них. рямої і повної кореляції між ступенем дефльов ності т вмістом фізичної глини в орному ш рі грунтів не виявлено.

олегшення гр нулометричного скл ду дефльов них грунтів відбув ється вн слідок зменшення вмісту мулу і дрібного пилу. окрем , вміст мулистої фр кції в орномуш рі дерново-сл бкопідзолистих дефльов них грунтів ст новить 0,40-3,16\%, дерновосередньопідзолистих - 3,32-4,72\%. міст дрібного пилу в орному ш рі різного ступеня дефльов них грунтів - 0,60-3,28 \% [2]. підорній ч стині профілю дефльов них дерново-підзолистих грунтів вміст і розподіл гр нулометричних фр кцій т кий же, як у недефльов них відмін.

бчислені зн чення відносного винесення бо н гром дження мулу 3 . оссовичем, свідч ть, що для дефльов них дерново-підзолистих грунтів х р ктерні перев жно винесення мулу з орних горизонтів (від -37,14 до -62,02\%) і тенденція до збільшення його вмісту в ілюві льних горизонт х. е спричинене н с мперед видув нням мулистих фр кцій вітром, т кож їхнім винесенням дрен жними вод ми вглиб 
профілю. рофіль дефльов них грунтів різко диференційов ний, ступінь диференці ції $\mathrm{S}$ досяг є 4,41-10,87 [2].

уттєвіших тр нсформ цій з зн є гр нулометричний скл д грунтів ун слідок осушув льних меліор цій. сушення дерново-підзолистих грунтів гонч рним дрен жем спричинило низку змін в інтенсивності т спрямов ності елемент рних грунтових процесів. ізк змін водно-повітряного режиму, пов'яз н зі зниженням рівня грунтових вод, зумовил посилення фільтр ційних процесів у грунті т , відповідно, ктивіз цію лесив жу. ісля осушення в грунт х виявил сь тенденція до полегшення гр нулометричного скл ду $[1,2]$. йсуттєвіші зміни відбулись у вмісті н ймобільніших гр нулометричних фр кцій - мулу і дрібного пилу. осилення низхідних потоків дрен жних вод призвело до винесення мулу і дрібного пилу з верхніх горизонтів грунту т кумуляції їх у нижчих горизонт х. собливо інтенсивно винесення мулу і дрібного пилу відбув ється в перші роки проведення осушув льних меліор цій. 28 років осушення вміст мулу в гумусово-елюві льному горизонті дерново-підзолистих зв'язнопіш них грунтів зменшився н $0,80 \%$, у супіщ них відмін - н 6,76-7,40\% (т бл. 1). елюві льному горизонті $\mathrm{h}$ досліджув них грунтів вміст мулу зменшився в середньому н $3,60-8,04 \%$.

p нулометричний скл д дерново-підзолистих грунтів лого олісся Granulometric composition of sod-podzolic soils of Male Polissia

\begin{tabular}{|c|c|c|c|c|c|c|c|c|c|}
\hline \multirow{3}{*}{$\begin{array}{r}\text { енетичні } \\
\text { горизонти }\end{array}$} & \multicolumn{9}{|c|}{ озміри фр кцій, мм } \\
\hline & \multicolumn{3}{|c|}{ фізичн глин , <0,01 } & \multicolumn{3}{|c|}{ дрібний пил, 0,005-0,001 } & \multicolumn{3}{|c|}{ мул >0,001 } \\
\hline & 1 & 2 & $1-2$ & 1 & 2 & $1-2$ & 1 & 2 & $1-2$ \\
\hline \multicolumn{10}{|c|}{ ерново-сл бкопідзолисті зв'язнопіщ ні грунти н водно-льодовикових відкл д х } \\
\hline & 8,03 & 6,40 & $-1,63$ & 2,84 & 1,60 & $-1,24$ & 4,00 & 3,20 & $-0,80$ \\
\hline $\mathrm{e}$ & 7,92 & 5,60 & $-2,32$ & 3,72 & 1,20 & $-2,52$ & 2,73 & 2,10 & $-0,63$ \\
\hline $\mathrm{p}$ & 6,72 & 3,60 & $-3,12$ & 3,05 & 0,40 & $-2,65$ & 3,34 & 2,40 & $-0,94$ \\
\hline \multirow[t]{2}{*}{$\mathrm{i}$} & 6,53 & 4,40 & $-2,13$ & 1,02 & 0,80 & $-0,22$ & 2,82 & 2,80 & $-0,02$ \\
\hline & 16,19 & 17,90 & $+1,71$ & 2,64 & 4,20 & $+1,56$ & 10,75 & 11,60 & $+0,85$ \\
\hline \multicolumn{10}{|c|}{ ерново-сл бк } \\
\hline & 17,00 & 10,80 & $-6,20$ & 4,12 & 4,80 & $+0,68$ & 11,00 & 3,60 & $-7,40$ \\
\hline $\mathrm{h}$ & 17,68 & 10,00 & $-7,62$ & 1,92 & 4,40 & $+2,48$ & 12,04 & 4,00 & $-8,04$ \\
\hline $\mathrm{e}$ & 14,12 & 13,00 & $-1,12$ & 1,20 & 5,80 & $+4,60$ & 10,08 & 7,80 & $-2,28$ \\
\hline $\mathrm{p}$ & 17,12 & 12,80 & $-4,32$ & 6,20 & 3,20 & $-3,00$ & 10,12 & 8,40 & $-1,72$ \\
\hline \multirow[t]{2}{*}{ i } & 13,40 & 6,00 & $-7,40$ & 3,96 & 1,20 & $-2,76$ & 8,40 & 4,00 & $-4,40$ \\
\hline & 14,64 & 14,80 & $+0,16$ & 3,16 & 3,60 & $+0,44$ & 10,22 & 8,80 & $-1,42$ \\
\hline \multicolumn{10}{|c|}{ ерново-середньопідзолисті супіш ні грунти н водно-льодовикових відкл дх } \\
\hline & 16,23 & 10,40 & $-5,30$ & 3,55 & 2,00 & $-1,55$ & 11,56 & 4,80 & $-6,76$ \\
\hline $\mathrm{h}$ & 12,56 & 8,80 & $-3,76$ & 4,72 & 2,80 & $-1,92$ & 7,60 & 4,00 & $-3,60$ \\
\hline $\mathrm{e}$ & 17,40 & 15,60 & $-1,80$ & 2,60 & 2,40 & $-0,20$ & 11,88 & 9,60 & $-2,28$ \\
\hline $\mathrm{p}$ & 13,80 & 12,80 & $-1,00$ & 1,56 & 3,80 & $+2,24$ & 5,24 & 4,90 & $-0,34$ \\
\hline \multirow[t]{2}{*}{$\mathrm{i}$} & 9,00 & 8,00 & $-1,00$ & 3,08 & 2,00 & $-1,08$ & 4,84 & 5,20 & $+0,36$ \\
\hline & 28,00 & 29,40 & $+1,40$ & 10,20 & 9,60 & $-0,60$ & 15,56 & 18,70 & $+3,14$ \\
\hline
\end{tabular}

р и м і т к : 1 - д ні до осушення; 2 - д ні після осушення. 
гідно з пок зник ми оцінки фізичної дегр д ції грунтів кр їни з зменшенням вмісту фізичної глини ( . люк т ін., 2013), дерново-підзолисті грунти з зн ли дегр д ції від помірного (середнього) до к т строфічного ступеня. тр ти фізичної глини ст новлять 20,3-36,5 \% від вихідного рівня.

3 пов жч нням гр нулометричного скл ду грунтів простежується тенденція до збільшення винесення мулистої фр кції. евисок різниця у вмісті мулу зв'язнопіщ них грунтів до і після осушення пов'яз н з низьким вихідним його вмістом у грунті. м теринській породі з фіксов но як збільшення вмісту мулу н $0,85-3,14 \%$, т к і зменшення н 1,42\%. евідповідність кількості мулу, винесеного 3 верхніх горизонтів і відкл деного в м теринській породі, зумовлен вимив нням його через дрен жну систему [2].

ісля осушення в грунт х виявлено зміни вмісту дрібного пилу. цьому р зі однон прямлених тенденцій змін нем є. одних вип дк х вміст дрібного пилу зменшився н 1,24-1,55\%, в іншому - збільшився н $0,68 \%$ у горизонті . Г лом вміст фізичної глини в орному горизонті дерново-підзолистих зв'язнопіщ них грунтів зменшився н 1,63\%, супіщ них - н 5,30-6,20\% (див. т бл. 1). меншення вмісту фізичної глини в орному горизонті зумовило зміну гр д ції дерново-підзолистих супіщ них грунтів з гр нулометричним скл дом до зв'язнопіщ них [2].

учні грунти лого олісся, сформов ні н водно-льодовикових відкл д х, м ють піщ нисто-легкосуглинковий т середньосуглинковий гр нулометричний скл д. ум фр кцій фізичної глини в гумусовому горизонті легкосуглинкових відмін ст новить $26,74-29,84 \%$, середньосуглинкових - 34,32-34,72 \%. рофільний розподіл фізичної глини вирізняється здебільшого поступовим зменшенням її вмісту вглиб профілю. ля фр кції мулу х р ктерне незн чне зрост ння в перехідному горизонті р і поступове зменшення з глибиною.

днозн чності щодо втр т чи н гром дження мулу у профілі лучних грунтів, сформов них н водно-льодовикових відкл д х, нем є. гідно з розр хунк ми, у верхній гумусов ній ч стині профілю з фіксов но як н гром дження мулу від $+2,64$ до $+34,29 \%$, т к і винесення від $-4,17$ до $-10,34 \%$. одібні тенденції простежуються і в горизонт х, що з ляг ють нижче. к різнон прямленість спричинен, н с мперед, тр нсформ цією елемент рних грунтових процесів ун слідок осушення (інтенсифік ція промивного водного режиму, посилення внутрішньогрунтового вивітрюв ння) т сільськогоспод рського використ ння грунтів. учні грунти вирізняються перев жно сл бкою і середньою, менше - сильною диференці цією профілю з вмістом мулу, ступінь диференці ції $\mathrm{S}$ ст новить 0,91-1,96 [2].

р нулометричний скл д лучних грунтів, сформов них н елювії верхньокрейдових мергелів, перев жно піщ нисто-середньосуглинковий, в жкосуглинковий т пилув толегкоглинистий, що зумовлено особливостями грунтотворних порід. ум фр кцій фізичної глини в гумусовому горизонті к середньосуглинкових грунтів ст новить $39,00 \%$, в жкосуглинкових - 46,08-59,36 \%, легкоглинистих - 60,44-72,48 \%, колив ючись у незн чних меж х бо поступово збільшуючись униз по профілю. ступенем диференці ції грунтів з лежно від вмісту мулу н леж ть до сл бко, сильно і різко диференційов них [2].

рив ле сільськогоспод рське використ ння лучних грунтів і осушув льні меліор ції спричинили зміни в їхньому гр нулометричному скл ді. окрем , н мітил сь тенденція до його полегшення вн слідок вимив ння мулистої т пилув тих фр кцій з 
верхніх горизонтів т їхньої кумуляції в перехідному до м теринської породи горизонті (h) і м теринській породі (т бл. 2).

p нулометричний скл д лучних грунтів лого олісся Granulometric composition of meadow soils of Male Polissia

\begin{tabular}{|c|c|c|c|c|c|c|c|c|c|}
\hline \multirow{3}{*}{$\begin{array}{r}\text { енетичні } \\
\text { горизонти }\end{array}$} & \multicolumn{9}{|c|}{ озміри фр кцій, мм } \\
\hline & \multicolumn{3}{|c|}{ фізичн глин , <0,01 } & \multicolumn{3}{|c|}{ дрібний пил, 0,005-0,001 } & \multicolumn{3}{|c|}{ мул >0,001 } \\
\hline & 1 & 2 & $1-2$ & 1 & 2 & $1-2$ & 1 & 2 & $1-2$ \\
\hline \multicolumn{10}{|c|}{ учні неглибокі піщ нисто-легкосуглинкові грунти н водно-льодовикових відкл д $x$} \\
\hline & 29,68 & 26,00 & $-3,68$ & 4,77 & 9,60 & $+4,83$ & 14,43 & 6,80 & $-7,63$ \\
\hline & 39,20 & 27,60 & $-11,60$ & 3,36 & 7,60 & $+4,24$ & 10,88 & 8,40 & $-2,48$ \\
\hline $\mathrm{p}$ & 37,36 & 14,40 & $-22,96$ & 3,76 & 3,20 & $-0,56$ & 23,56 & 7,60 & $-15,96$ \\
\hline $\mathrm{h}$ & 31,12 & 15,60 & $-15,52$ & 7,20 & 6,80 & $-0,40$ & 18,20 & 5,60 & $-12,60$ \\
\hline $\mathrm{P}(\mathrm{h})$ & 27,56 & 19,20 & $-8,36$ & 6,16 & 7,40 & $+1,24$ & 16,60 & 9,60 & $-7,00$ \\
\hline 1 & 25,20 & 20,80 & $-4,40$ & 8,64 & 6,00 & $-2,64$ & 12,28 & 10,80 & $-1,48$ \\
\hline 2 & 26,80 & 28,40 & $+1,60$ & 14,28 & 11,40 & $-2,88$ & 6,28 & 12,80 & $+6,52$ \\
\hline \multicolumn{10}{|c|}{ учні неглибокі піщ нисто-середньосуглинкові грунти н водно-льодовикових відкл д х } \\
\hline & 32,24 & 25,20 & $-7,40$ & 11,24 & 13,20 & $+1,96$ & 15,20 & 6,00 & 9,20 \\
\hline & 29,20 & 26,80 & $-2,40$ & 9,76 & 12,80 & $+3,04$ & 17,64 & 8,80 & 8,84 \\
\hline $\mathrm{p}$ & 26,12 & 24,40 & $-1,72$ & 10,20 & 11,60 & $+1,40$ & 12,68 & 7,60 & $-5,08$ \\
\hline $\mathrm{h}$ & 17,16 & 17,20 & $-0,40$ & 5,04 & 4,80 & $-0,24$ & 10,32 & 9,20 & $-1,12$ \\
\hline $\mathrm{P}(\mathrm{h})$ & 17,04 & 17,80 & $+0,76$ & 1,12 & 3,30 & $+2,18$ & 10,52 & 9,80 & $-0,72$ \\
\hline 1 & 7,40 & 13,20 & $+5,80$ & 3,68 & 2,40 & $-1,28$ & 3,32 & 8,00 & $+4,68$ \\
\hline 2 & 15,20 & 18,60 & $+3,40$ & 10,08 & 5,90 & $-4,18$ & 4,24 & 10,10 & $+5,86$ \\
\hline \multicolumn{10}{|c|}{ учні неглибокі к рбон тні піш нисто-середньосуглинкові грунти н елювї мергелів } \\
\hline & 48,64 & 45,60 & $-3,30$ & 13,86 & 7,20 & $-6,06$ & 29,18 & 25,20 & $-3,98$ \\
\hline $\mathrm{p}$ & 46,14 & 43,60 & $-2,54$ & 12,16 & 5,60 & $-6,56$ & 27,08 & 26,00 & $-1,08$ \\
\hline $\mathrm{h}$ & 51,76 & 49,60 & $-2,16$ & 16,35 & 16,40 & $+0,05$ & 28,24 & 20,80 & $-7,44$ \\
\hline $\mathrm{P}(\mathrm{h})$ & 48,52 & 46,00 & $-2,52$ & 16,02 & 8,80 & $-7,22$ & 24,51 & 26,80 & $+2,29$ \\
\hline 1 & 46,41 & 48,60 & $+2,19$ & 11,72 & 9,60 & $-2,12$ & 24,16 & 27,00 & $+2,84$ \\
\hline
\end{tabular}

р и мі т к : 1 - д ні до осушення; 2- д ні після осушення.

міст мулу в гумусовому горизонті лучних грунтів зменшився н 3,98-9,20\%. лучних грунт $\mathrm{x}$, сформов них н водно-льодовикових відкл д $\mathrm{x}$, $\mathrm{y}$ р зі пов жч ння гр нулометричного скл ду втр ти мулу зрост ють. рібний пил 3 зн є інтенсивного вимив ння з профілю лучних грунтів, сформов них н елювії мергелів. чевидно, це пов'яз не з тріщинув тістю мергелів, де великі шп ри створюють сприятливі умови для інтенсивних низхідних потоків води.

олегшення гр нулометричного скл ду грунтів ун слідок вимив ння мулу і, ч стково, дрібного пилу дрен жними вод ми з верхніх горизонтів т, відповідно, їхнє опіщ нення зумовили зміни гр д ції грунтів 3 гр нулометричним скл дом. окрем , лучні грунти, які до осушення м ли легкосуглинковий гр нулометричний скл д, після осушення ст ли супіщ ними, середньосуглинкові грунти - легкосуглинковими. лучних к рбон тних грунт х р д ція гр нулометричного скл ду лучних к рбон тних грунт х змінил ся: 3 в жкосуглинкових вони ст ли середньосуглинковими. учні 
неглибокі грунти н водно-льодовикових відкл д х з зн ли гр нулометричної дегр д ції сл бкого т середнього ступеня, втр ти фізичної глини ст новлять 12,4-21,8 \% від вихідного рівня, лучні к рбон тні - сл бкого, втр ти фізичної глини ст новлять 6,3\%.

ернові глибокі глеюв ті і глейові грунти лого олісся, сформов ні н воднольодовикових, д вньо люві льних т суч сних люві льних відкл д х, м ють, здебільшого, супіщ ний і піщ нисто-легкосуглинковий, рідше - зв'язнопіщ ний і піщ нисто-середньосуглинковий гр нулометричний скл д [1, 2]. міст фр кцій фізичної глини в гумусовому горизонті грунтів зв'язно-піщ ного гр нулометричного скл ду ст новить 6,20 \%, супіщ них - 12,48-16,96 \%, піщ нисто-легкосуглинкових - 23,12\%, піщ нисто-середньосуглинкових - 31,12-33,40\%. глибиною по профілю вміст фізичної глини м є тенденцію як до збільшення, т к і до зменшення. еред гр нулометричних фр кцій у горизонті зв’язнопіщ них і супіщ них відмін перев ж $є$ дрібний пісок.

ля дернових грунтів х р ктерні як н гром дження, т к і винесення мулу по профілю. собливо інтенсивне н гром дження мулу (до $+222,41 \%)$ з фіксов но в грунт х 3 неглибоким з ляг нням щільних глейових горизонтів бо ортз ндових ш рів. тупінь диференці ції профілю $\mathrm{S}$ з вмістом мулу в зв'язно-піщ них і супіщ них грунт $\mathrm{x}$ сл бкий і середній, зн чення $\mathrm{S}$ ст новить 0,88-1,38. пов жч нням гр нулометричного скл ду простежується зрост ння ступеня диференці ції профілю [2].

ернові глибокі глеюв ті к рбон тні грунти, сформов ні н елювії верхньокрейдових відкл дів, м ють середньо- т в жкосуглинковий гр нулометричний скл д. міст фр кцій фізичної глини в гумусовому орному горизонті к колив ється в меж х 39,00$58,44 \%$. глиб до м теринської породи кількість фізичної глини зрост є. міст мулу по генетичних горизонт х м є низьку в рі бельність. еред гр нулометричних фр кцій здебільшого перев ж є грубий пил, рідше - дрібний.

езульт ти досліджень з свідчили, що в профілі дернових глибоких к рбон тних грунтів відбув ється винесення (від $-4,59$ до -20,83\%) і н гром дження (від +1,50 до $+40,88 \%$ ) мулистої фр кції (з . оссовичем). е зумовлено процес ми внутрішньогрунтового вивітрюв ння т інтенсивністю дрен жу з ч с осушення. ступенем диференці ції профілю з лежно від вмісту мулу грунти н леж ть до сл бко- і середньодиференційов них, пок зник $\mathrm{S}$ колив ється в меж х 0,97-1,58 [2].

сушув льні меліор ції призвели до полегшення гр нулометричного скл ду дернових грунтів ун слідок винесення мулу т дрібного пилу з верхніх горизонтів т їхньої кумуляції в перехідному до м теринської породи горизонті і в м теринській породі (див. т бл. 3).

результ т ми досліджень, вміст мулистої фр кції в гумусовому горизонті після осушення зменшився н $0,50-3,97 \%$, дрібного пилу - н 0,04-3,61\%. пов жч нням гр нулометричного скл ду втр ти мулу і дрібного пилу зрост ють. міст фізичної глини після осушення зменшився н 1,27-6,39\% (див. т бл. 3). ернові глибокі піщ нисто-легкосуглинкові грунти після осушення х р ктеризують як супіщ ні, дернові глибокі к рбон тні в жкосуглинкові - як середньосуглинкові [2]. ернові грунти з зн ли гр нулометричної дегр д ції сл бкого т середнього ступеня, втр ти фізичної глини ст новлять 17,8-24,2 \% від вихідного рівня.

олегшення гр нулометричного скл ду меліоров них грунтів через винесення дрібного пилу і мулу н лежить до к тегорії дегр д ційних процесів, оскільки призводить до ктивіз ції вітрової ерозії, погіршення структурно- грег тного скл ду грунтів, 
водно-фізичних вл стивостей, дегуміфік ції, ридиз ції, зниження їхньої бонітетної і грошової в ртості. ому полегшення гр нулометричного скл ду меліоров них грунтів необхідно з числяти до “гр нулометричної дегр д ції” (термін з пропонов ний втором) і розгляд ти як один видів фізичної дегр д ції грунтів.

блиия 3

p нулометричний скл д дернових грунтів лого олісся Granulometric composition of sod soils of Male Polissia

\begin{tabular}{|c|c|c|c|c|c|c|c|c|c|}
\hline \multirow{3}{*}{$\begin{array}{r}\text { енетичні } \\
\text { горизонти }\end{array}$} & \multicolumn{9}{|c|}{ озміри фр кцій, мм } \\
\hline & фізичн & I глин & $<0,01$ & \multicolumn{3}{|c|}{ дрібний пил, 0,005-0,001 } & \multicolumn{3}{|c|}{ мул >0,001 } \\
\hline & 1 & 2 & $1-2$ & 1 & 2 & $1-\quad 2$ & 1 & 2 & $1-2$ \\
\hline \multicolumn{10}{|c|}{ ернові глибокі зв'язнопіщ } \\
\hline & 6,87 & 5,60 & $-1,27$ & 1,24 & 1,20 & $-0,04$ & 3,30 & 2,80 & $-0,50$ \\
\hline & 5,83 & 4,00 & $-1,83$ & 1,41 & 0,40 & $-1,01$ & 3,70 & 2,00 & $-1,70$ \\
\hline \multirow[t]{2}{*}{ (h) } & 3,86 & 6,40 & $+2,54$ & 1,56 & 0,40 & $-1,16$ & 1,65 & 3,20 & $+1,55$ \\
\hline & 6,42 & 7,80 & $+1,38$ & 0,96 & 0,90 & $-0,06$ & 4,56 & 5,80 & $+1,24$ \\
\hline \multicolumn{10}{|c|}{ ернові глибокі супіщ ні грунти н водно-льодовикових відкл д х } \\
\hline & 12,53 & 10,30 & $-2,23$ & 2,18 & 3,20 & $+1,02$ & 9,77 & 5,80 & $-3,97$ \\
\hline & 7,21 & 6,40 & $-0,81$ & 2,58 & 2,90 & $+0,32$ & 2,81 & 2,40 & $-0,41$ \\
\hline $\mathrm{h}$ & 9,33 & 6,80 & $-2,53$ & 1,22 & 1,20 & $-0,02$ & 7,02 & 6,80 & $-0,22$ \\
\hline \multirow[t]{2}{*}{ (h) } & 9,68 & 10,70 & $+1,02$ & 3,82 & 2,60 & $+1,22$ & 2,16 & 6,90 & $+4,74$ \\
\hline & 15,11 & 16,90 & $+1,59$ & 2,83 & 2,70 & $-0,13$ & 9,16 & 12,10 & $+2,94$ \\
\hline \multicolumn{10}{|c|}{ ернові глибокі піщ нисто-легкосуглинкові грунти } \\
\hline & 24,79 & 18,80 & $-5,99$ & 8,68 & 6,00 & $-2,68$ & 9,24 & 6,80 & $-2,44$ \\
\hline & 24,04 & 22,80 & $-1,24$ & 4,14 & 6,40 & $+2,26$ & 15,52 & 11,60 & $-3,92$ \\
\hline $\mathrm{h}$ & 16,36 & 19,70 & $+3,34$ & 0,98 & 5,80 & $+4,82$ & 11,48 & 10,10 & $-1,38$ \\
\hline \multirow[t]{2}{*}{ (h) } & 2,82 & 15,60 & $+12,78$ & 0,16 & 4,80 & $+4,64$ & 1,98 & 10,40 & $+8,42$ \\
\hline & 39,51 & 42,40 & $+2,89$ & 8,02 & 6,20 & $-1,82$ & 20,99 & 26,20 & $+5,21$ \\
\hline \multicolumn{10}{|c|}{ ернові глибокі к рбон тні піщ нисто-середньосуглинкові грунти н елювї мергелів } \\
\hline $\mathrm{K}$ & 49,79 & 40,40 & $-6,39$ & 17,21 & 13,60 & $-3,61$ & 17,28 & 14,40 & $-2,88$ \\
\hline $\mathrm{K}$ & 36,54 & 34,60 & $-1,94$ & 14,05 & 12,40 & $-1,65$ & 16,44 & 13,20 & $-3,24$ \\
\hline hK & 38,37 & 33,60 & $-4,77$ & 10,53 & 9,20 & $-1,33$ & 21,69 & 16,00 & $-5,69$ \\
\hline$(\mathrm{h})_{\mathrm{K}}$ & 37,42 & 38,00 & $+0,58$ & 10,82 & 10,00 & $-0,82$ & 17,91 & 18,40 & $+0,49$ \\
\hline $\mathrm{K}$ & 38,21 & 42,70 & $+4,49$ & 11,74 & 12,50 & $+0,76$ & 18,23 & 20,60 & $+2,37$ \\
\hline
\end{tabular}

р и м і т к : 1 - д ні до осушення; 2- д ні після осушення.

иділення гр нулометричної дегр д ції грунтів в жливе для уточнення типології дегр д ційних процесів. кож гр нулометричну дегр д цію рекомендов но використовув ти, х р ктеризуючи зміни фізичних вл стивостей грунтів після осушення, оцінюючи рівні дегр д ції грунтів, їхній гроекологічний ст н.

тже, н ліз результ тів дослідження гр нулометричного скл ду осушених грунтів лого олісся д є змогу зробити т кі висновки:

- осушення перезволожених грунтів лого олісся вплинуло н грунтові режими i процеси, призвело до змін фізичних т водно-фізичних вл стивостей грунтів, спричинило розвиток низки дегр д ційних процесів, зокрем дефляційних; 
- у дефльов них дерново-підзолистих грунт х простежується тенденція до полегшення гр нулометричного скл ду вн слідок дефляційного зменшення вмісту мулу і дрібного пилу в гумусово-елюві льних горизонт х;

- осушув льні меліор ції призвели до полегшення гр нулометричного скл ду дерново-підзолистих, лучних і дернових грунтів через винесення мулу і дрібного пилу дрен жними вод ми вн слідок посилення процесів лесив жу з верхніх горизонтів і їхню кумуляцію в нижніх горизонт х. осушених грунт х відбув ється змін гр д ції грунтів н рівні різновиду з гр нулометричним скл дом бо н ближення грунтів до зміни гр д ції. олегшення гр нулометричного скл ду в осушених грунт х рекомендов но розгляд ти як гр нулометричну дегр д цію. сушені грунти лого олісся з зн ли гр нулометричної дегр д ції сл бкого, середнього т к т строфічного ступеня.

1. ськевич . ., озняк . . сушені мінер льні грунти лого олісся : оногр фія. ьвів : ид вничий центр імені в н р нК , 2004. 256 с.

2. ськевич . . еоретичні основи і прикл дні спекти дегр д ції грунтів лого олісся: дис. ... Д-р геогр. н ук : 11.00.05. ьвів, 2010. 851 с.

3. егр д ция и охр н почв / под общей ред. к д. . . обровольского. . . зд-во оск. ун-т , 2002. 654 с.

4. йдельм н. . р нулометрический сост в почв и его изменение под влиянием мелиор ции / енезис и экологические основы мелиор ции почв и л ндш фтов. . : зд-во , 2009. . 335-336.

5. едведев . ., ктионов . . р нулометрический сост в почв кр ины (генетический, экологический и грономический спекты). рьков : построф, 2011. 292 c.

6. едведев . . изическ я дегр д ция черноземов. и гностик . ричины. ледствия. редупреждение. рьков : ородск я типогр фия, 2013. 324 с.

7. едведев . . гро- и экофизик почв. рьков : “ олос т я типогр фия”, 2015. 312 c.

8. еории и методы физики почв /под ред. . . еин , . . рп чевского. . : риф и , 2007. 616 с.

9. ичин . . ин мік гр нулометричного скл ду осушених гідроморфних грунтів олісся // існ. гр р. н уки. . : 2001. № 6. . 79-80.

10. еин . . урс физики почв. . : зд-во , 2005. 432 с.

11. еин. ., онч ров . . грофизик . остов н/ . : еникс, 2006. 400 с.

\section{REFERENCES}

1. Haskevych, V., \& Poznjak, S. (2004). Dried mineral Soils of Small Polissya. Lviv: Publishing Centre of Ivan Franko National University of Lviv, 229 p. (in Ukrainian).

2. Haskevych, V. G. (2010). Theoretical Fundamentals and Applied Aspects of Soils Degradation of Small Polissya (Unpublished doctoral dissertation). Ivan Franko National University of Lviv, Lviv, 851 p. (in Ukrainian).

3. Dobrovolski, G. V. (2002). Degradation and guard of soils. Moscow: Moscow University Publishing house, 654 pp. (in Russian). 
4. Zaidelman, F. R. (2009). The granulometric composition of soils and its change under the influence of melioration. In Genesis and ecological bases of soil and landscape reclamation (pp. 335-336). Moscow: Moscow University Publishing house (in Russian).

5. Medvedev, V. V., \& Laktionova, T. N. (2011). Texture of Ukrainian Soils (genetic, environmental and agronomical aspects). Kharkov: Apostrof, 292 p. (in Russian).

6. Medvedev, V. V. (2013). Physical degradation of chernozems. Diagnostics. The reasons. Consequences. The prevention. Kharkov: Gorodskaya tipografiya, 324 p. (in Russian).

7. Medvedev, V. V. (2015). Soil agronomic and environmental physics. Kharkiv: Smuhasta typografiya, 312 p. (in Ukrainian).

8. Shein, E. V., \& Karpachevskyi, L. O. (Eds.) (2007). Theories and methods of physics of soils. Moscow: Grif and K, 616 p. (in Russian).

9. Tychyna, L. K. (2001). Dynamics of granulometric composition of drained hydromorphic soils of Polissya. Visnyk of Agrarian Science, 6, 79-80 (in Ukrainian).

10. Shein, E. V. (2005). Course physics of soils. Moscow: Moscow University Publishing house, 432 p. (in Russian).

11. Shein, E. V., \& Goncharov, V. M. (2006). Agrophysics. Rostov-on-Don: Feniks, 400 p. (in Russian).

\title{
CHANGE OF GRANULOMETRIC COMPOSITION OF DRAINED SOILS OF MALE POLISSIA IN THE CONTEXT OF DEVELOPMENT OF DEGRADATION PROCESSES
}

\author{
Volodymyr Haskevych \\ Ivan Franko National University of Lviv, \\ P. Doroshenko St., 41, UA - 79007 Lviv, Ukraine, \\ e-mail: haskevich_vg@ukr.net
}

Sod-podzolic (Albenuvisoils Gleyic), meadow (Gleyic Chernic Phaeozems) and sod (Arenosols) soils are typical for Male Polissia. In the natural state, these soils are waterlogged, characterized by unsatisfactory physical properties, unsuitable for agricultural use. After the drainage reclamation, the soils are intensively used as arable land, pastures, and hayfields.

The drainage has led to a significant decrease in groundwater levels, increased the washing water regime, intensified the processes of lessivage, which affected the physical properties of soils, in particular, granulometric composition. In the reclaimed areas, aridification and deflationary processes intensified. In deflated sod-podzolic soils, the relief of granulometric composition has been reducing due to decrease in the content of sludge and fine dust in the arable horizons.

Granulometric composition of soils undergoes more significant transformations as a result of the intensification of flushing water regime after drainage. The content of physical clay in the arable horizon of sod-podzolic fixed- sandy soils decreased by $1.63 \%$, and of the sandy loam soils - by 5.30 $6.20 \%$. In the humus-accumulating arable horizon of meadow soils, the physical clay content decreased by $2.40-1.60 \%$, that of sod soils - by $1.27-6.39 \%$. Washing off with drainage waters of small 
granulometric fractions results in an increase in the content of sand fractions and facilitates the granulometric composition of soils, changes in soil gradation at the level of variety.

Decrease in the content of physical clay causes deterioration of physical, physical-and-chemical, agronomic properties of soils, and therefore causes the development of degradation processes: nonstructural, deflation, dehumification, degradation of water and air and nutrient regimes, aridification. This gave rise to the idea of referring to the granulometric composition facilitation of drained soils as "granulometric degradation" and classifying it as physical degradation of soils.

Key words: Male Polissia, drainage reclamation, soils, granulometric composition, physical clay, granulometric degradation. 